\title{
Çanakkale Şehitler Abidesi Şevi Dikey Bahçe Tasarım Önerisi
}

\author{
Yavuz ALKAN*1] \\ ${ }^{1}$ Çanakkale Onsekiz Mart Üniversitesi, Lapseki Meslek Yüksekokulu, Peyzaj ve Süs Bitkileri Bölümü, 17800, \\ Çanakkale, Türkiye
}

(Alınış / Received: 01.01.2020, Kabul / Accepted: 13.03.2020, Online Yayınlanma / Published Online: 20.04.2020)

\author{
Anahtar Kelimeler \\ Canakkale, \\ Şehitler Abidesi, \\ Dikey bahçe, \\ Planlama, \\ Tasarım.
}

\begin{abstract}
Özet: Günümüzde kentler ivmesi artan biçimde plansız bir gelişmeye maruz kalmaktadır. Bu da doğayı kendinden uzaklaştırmaktadır. Bu açığın kapatılmasına yönelik yeterli sayı ve miktarda açık ve yeşil alan planlamalarının yapıldığını söylemek güçtür. Bu süreçte farklı uygulamaların kent tekstüründe yer aldıklarını görmekteyiz. Çatı ve teras bahçeleri, dikey orman uygulamaları bunların başında gelmektedir. Dikey bahçe uygulamaları kullanım amacına göre değişiklik göstermektedir. Mimari yapıların yoğun olduğu, açık ve yeşil alanların ise nispeten çok az olduğu kent dokularında özellikle havadaki karbondioksit, karbonmonoksit gibi gazların miktarını en aza indirgemek, daha ılımlı ve estetik görünüm sağlamak, toprak kayması ve aşınmasının önüne geçmek gibi amaçlar için dikey bahçeler kullanılmaktadır. Bu çalışma Çanakkale Şehitler Abidesi'nde gerçekleştirilmiştir. Alanın denizle birleştiği sınıra kadar olan mesafesi oldukça dik bir yamaç özelliğindedir. Bu yamaçta yer alan toprak yapısalının zaman içinde iklimsel faktörler ve doğa olaylarının etkisiyle erozyona maruz kalması kaçınılmazdır. Bu çalışmada mevcut yamaç/şev alanın istinat duvarlarıyla teraslanması; teraslarda dikey ve yatay bitkilendirme çalışmaları ile şev stabilizasyonuna gidilmesi amaçlanmaktadır. Böylelikle alana estetik ve fonksiyonel kazanımlar sağlanması ön görülmektedir. Ayrıca Çanakkale Tarihi'nin anlam ve duygusunu ifade edebilen şekil ve sembollere yer verilerek șev alanın görünümüne anlamlı bir kimlik kazandırılması düşünülmektedir.
\end{abstract}

\section{Design Proposal of Vertical Garden on the Slope of Canakkale Martyrs Monument}

Keywords Canakkale, Martyrs Monument, Vertical garden, Planning, Design.

\begin{abstract}
Today, cities are increasingly exposed to unplanned development. This takes nature away from itself. It is difficult to say that adequate numbers and amount of open and green space planning have been made to close this vulnerability. In this process, we see that different applications are located in the city monopoly. Rooftop and terrace gardens, vertical forest applications are among them. Vertical garden applications vary depending on the purpose of use. Vertical gardens are used to ensure a moderate and aesthetic appearance, reducing the amount of gases such as carbon dioxide, carbon monoxide in the air in urban tissues where architectural structures are high, open and green areas are low, and to prevent landslides and wear. This study was conducted in Çanakkale Martyrs Monument. Fairly steep slope to the border area where it meets the sea the distance property. This is located on the slope of the soil erosion by the action of climatic factors on the structural and natural phenomena that is subject to time is inevitable. In this study, the existing slope/slope teraslanma the area with the retaining wall; slope stabilization planting of the terraces, it is intended to be driven with vertical and horizontal work. Thus, it is important to provide aesthetic and functional gains of the area. Also different shapes that can express the meaning and feeling of the history of the Dardanelles and symbols given to the appearance of a significant area of the slope is thought to be gained identity.
\end{abstract}




\section{Giriş}

Kent olgusunun var oluşundan bu yana yeșil alanların dinsel, toplumsal, sanatsal, tarımsal, ekolojik ve ekonomik amaçlı kullanıldıkları anlaşılmaktadır [1]. Kentsel yapılaşmaların yoğun olmadığı dönemlerde yeşil alan planlamalarının yeterli miktar ve alanda kentsel yapıda yer aldıkları görülmektedir. Ancak son yıllarda artan nüfus ve buna paralel artan yapılaşmaya bağlı olarak kent tekstüründe hem miktar/alan, hem de donatı kapsamında yetersizlikler dikkat çekmektedir [2-5]. Bu durum, yoğun ve iç içe girmiş çok katlı yapıların arasında yaşam mücadelesi veren insanın artan hava kirliliğiyle muhatap olmasını; ayrıca boş zaman değerlendirme aktiviteleri için son derece kısıtll imkanlar tesis etmesini kaçınılmaz kılmıștır [3]. Dolayısıyla, kent dokusundaki yeşil alan planlamaları ekstrem yeşil alan dinamikleriyle açığa çıkmış olup, pek çok fonksiyonellik ve estetik kapsamda gelişme göstermişlerdir [6]. Öyle ki, "çatı ve teras bahçeleri" ile başlayan bu dinamizm, "dikey bahçe" ve sonrasında "dikey orman" olarak bu gelişmede yerlerini aldıkları görülmektedir. Patric Blanc'in bitkilerin dikey yüzeylerde yetişebildiğini keşfetmesiyle bu uygulama hem konut içinde hem de açık ve yeşil alanlarda yaygınlaşan kullanım potansiyeli ile insan yaşamına entegre olmuştur [7]. Patrick Blanc dikey bahçelerde yaptığı çalışmalarla dünya çapında etkin bir rol üstlenmesinin yanında, yoğun yapılaşmanın görüldüğü kentlerde gerek iç mekan gerekse diş mekanlarda dikey bahçe kullanım alanlarının yaygınlaşmasında etkisi olmuştur [7]. Dikey bahçe kullanımlarının estetik boyutunun yanı sıra işlevsel boyutunun da oldukça yaygın olduğundan bahsedilebilir. Dikey bahçeler işlevsel olarak; enerji tasarrufu, ISı yalıtımı, iklimsel kazanımlar, kentlerde ısı adalarının bertarafı, hava bileşenlerinin dengelenmesi, kuş, böcek gibi canlılara yaşam alanı sunması ve yoğun yapılaşmaların arasında doğal ekosisteme imkan vermesi, birey psikolojisinde iyileştirmeler sağlaması yönünden etkin rol almaktadır [8-10]. Ayrıca, dikey bahçeler istinat duvarları kombinasyonunda dikey ve yatay bitkilendirmelerle şev stabilizasyonlarında önemli bir kullanımı da kapsamaktadır [11]. Dikey bahçe bitkilendirmelerinde duvarın teknik özellikleri ile bitkilerin işlevsel ve estetik kullanımlarının birbirlerini tamamlamaları önemli görülmektedir. Dikey cephede panel sistem, yeşil metal ve çit saksı tipi dikey bahçeler yer almaktadır [7]. $\mathrm{Bu}$ formasyonda yaygın olarak sarılıcı, sürünücü, yayılıcı ve tırmanıcı bitkiler tercih edilmektedir. Ayrıca dikey cephelerde yer yer alanın tarihine dokunuşlar yapmak amaciyla tematik kabartma resimler de (röliyef) planlanmaktadır. İstinat duvarı yatay alanında ise, derin kök yapan, az bakım isteyen, ekolojik ihtiyaçlar bakımından geniş tolerans gösteren ağaç, ağaççık ve çalı formunda bitkilendirmeler ağırlıklı olarak kullanılmaktadır [12]. İstinat duvarı bitkilendirmelerinin toz, rüzgar, güneş gibi çevresel şartlara karşı koruyucu rol üstlenmesi planlanmaktadır. Hatta son dönemlerde kentsel yaşamda dikey bahçelerin yenilebilir tarımsal ürünlerinin değerlendirilmesi ile de gündemde olduklarını görmekteyiz [13]. Zengin kullanım potansiyelleri doğrultusunda dikey bahçe uygulamasının Çanakkale Şehitler Abidesi şevinin mevcut bitkisel ve fiziki koşullarının, ekolojik ve jeolojik koşullarla birlikte değerlendirildiğinde alan için oldukça gerekli bir tasarım olduğu aşikardır. Çalışma kapsamında "dikey bahçe" uygulamasına yönelik planlama yaklaşımı Çanakkale Şehitler Abidesi örneğinde değerlendirilmiş olup, söz konusu tasarımla dikey bahçe yapısalının yapılış amaçları arasında istinat duvarlarının bitkilendirilmesi ile hem Şehitler Abidesi şevinin deprem, erozyon ve ekolojik faktörler etkisiyle zamanla kaymasının önüne geçilmiş olacak; hem de estetik açıdan alana pozitif peyzaj katkısı da sunulmuş olabilecektir. Çalışmada, uygun bitki popülasyonlarıla sağlanan bitkilendirme çalışması ve istinat duvarları kombinasyonuyla ortaya çıkan peyzaj planlamasının alana kazandırdıkları kapsamında öneriler geliştirilerek optimal alan kullanımına ulaşılması amaçlanmıştır.

\section{Materyal ve Metot}

Aralık 2019'da yürütülen çalışmada ana materyal olan Şehitler Abidesi, coğrafi konum itibariyle $40^{\circ} 2^{1}$ $55^{11}$ Kuzey Enlemi ile $26^{\circ} 14^{1} 92^{11}$ Doğu Boylamının çakıştı̆̆ koordinatlarda yer almaktadır (Şekil 1). 1960 yılında tamamlanarak, Çanakkale il sınırları kapsamında Eski Hisarlık Tepe üzerinde inşa edilmiş [14] ve Morto Koyuna bakısı olan Abide, Çanakkale Boğazı'na sınır olup, deniz seviyesinden $50 \mathrm{~m}$ yüksekte konumlanmış; 41,70 m boya sahiptir. 10'ar metrelik aralıklarla sıralanan ve her bir kolu 7,5 m olan L şeklindeki kutu gövdeli 4 ayak üzerinde, boyutları $25^{\prime} \mathrm{er} \mathrm{m}$ olan kare alan üzerinde yükselmiştir [15]. Ayaklar yine kutu gövdeli $5 \mathrm{~m}$ yüksekliğindeki takke kısmı ile birbirine bağlanarak inşaat tamamlanmıştır. Alan, Abide esas gövdesi ve tören alanından oluşan iki bölüme sahiptir. Temel zemini sert kalkerdir. 30 × 30 metre ebadinda bir şeref holü ile ve yine yaklaşıl 45 x 45 metre ebadında bir platform ile çevrilidir. Her iki seviyede taş kaplamalıdır. Şehitler Abidesi platformu 175 metre boyunda ve 45 metre eninde olup, platform yeșil alan birlikteliği ise yaklaşık $250 \mathrm{~m}$ uzunluğa ve $90 \mathrm{~m}$ ene sahiptir [16].

Çalışmada ilk olarak alanda yapılan gezi ve gözlemlerle alanın doğal bitki örtüsü tespit edilmiştir. Bu kapsamda Çanakkale Şehitler Abidesi șev alanında dikey bahçe tasarımı için teraslama bahçe tekniği ile bu alanın bitkilendirilmesi üzerine çalışmalar yapılmıştır. Çalışma, Şehitler Abidesi şevinde istinat duvarları yapımı, kabartma resim yapısall, bitkilendirme, ve öneriler olarak dört farklı aşamada geliştirilmiştir. Alanda uygun görülen tasarım aşamaları, aşağıda belirtilen iş akışı şeklinde 
gerçekleştirilebilir. 1. Alanın güney ve batı yönleri kapsamında 50 metre rakımdan yaklaşık 80 metrelik yatay mesafeyle deniz seviyesine inen șev, her iki yönlü olarak deniz seviyesinden 10'ar metrelik yükseklik ve $15^{\prime}$ er metrelik yatay zemin olacak şekilde 5 basamaklı teraslama sistemi ile istinat duvarlarının inșa edilmesi, 2. Diștan içe $15^{\prime}$ er metrelik yüzeye/zemine/yatay boyuta ve 10'ar metrelik dikey boyuta sahip her teras için amaca ve çevre ekolojisine uygun bitkilendirme tasarımlarının planlanması, 3. Teras duvarları yüzeyinde Çanakkale tarihine yönelik tematik figürlerin, sembollerin, şekillerin kabartmalı resimlerle (Röliyef) planlanması ile alanın kimliğine katkı sağlanması, 4. Bu çalışmalar sonucunda alanın kazanımları ile optimal alan kullanımı üzerinde öneriler geliştirilmiștir.

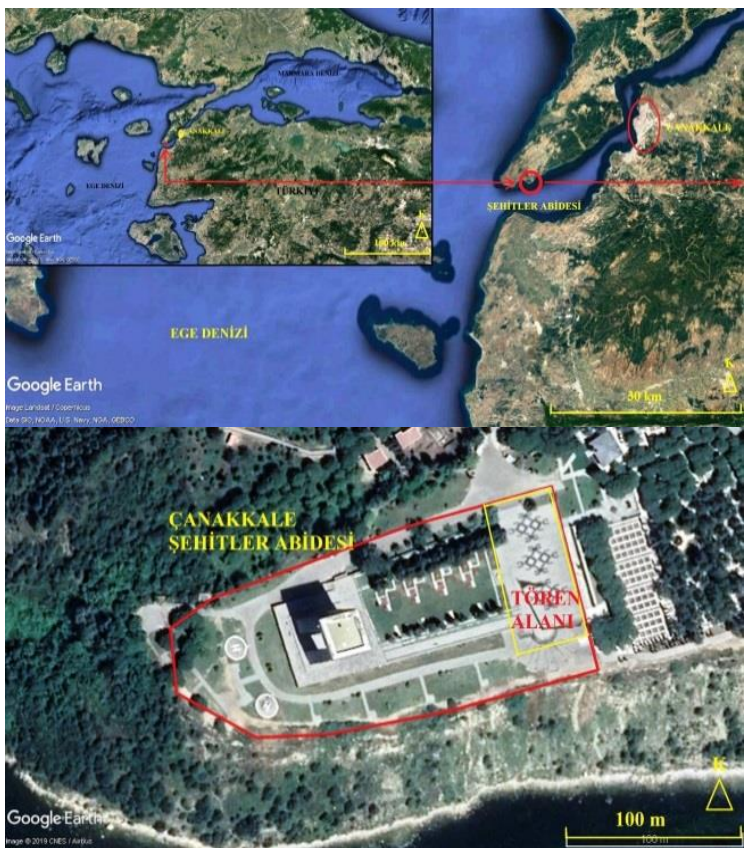

Şekil 1. Çanakkale Şehitler Abidesi coğrafi konumu ve mevcut durumu [17].

\section{Bulgular}

Dikey bahçe kullanımları, peyzaj değerlerine hem estetik, hem de işlevsel açıdan sunduğu alternatif uygulamalarla katkı sağlamaktadır. Estetik açıdan yatay ve dikey boyutta renk, şekil, hacim, doku gibi kriterler bakımından değerlendirilmektedirler (Şekil $2,3)$.

İşlevsel açıdan ise toprak yapısının ıslahı, toprak kaymasının önlenmesi, ekolojik, psikolojik ve sosyal kriterler bu kapsamda değerlendirilebilir (Şekil 4). Sınırları belirli dikey formda bitkilendirme çalışmalarına yönelik ilk dikey bahçelerin örneklerini Babil'in asma bahçeleri'nde görmekteyiz. Yaklaşı 25 yüzyıl öncesine uzanan bu bahçe uygulaması örneklerinin bu çalıșmada belirlenen tasarım örneği ile karşılaştırmasını Şekil 4'de görmek mümkündür $[8,19]$.

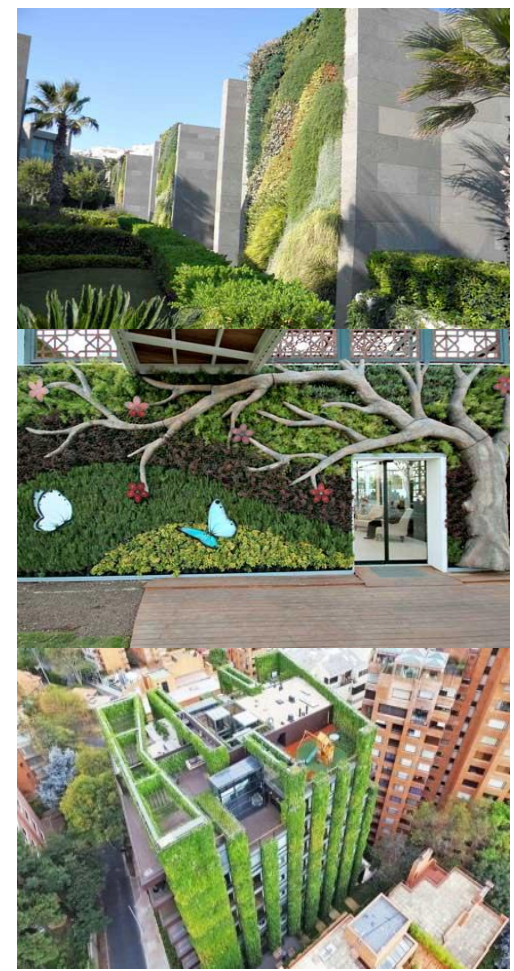

Şekil 2. Siralı olarak Swiss Otel /2013, Antalya EXPO/2016 ve Kolombiya'dan dikey bahçe örnekleri [18].
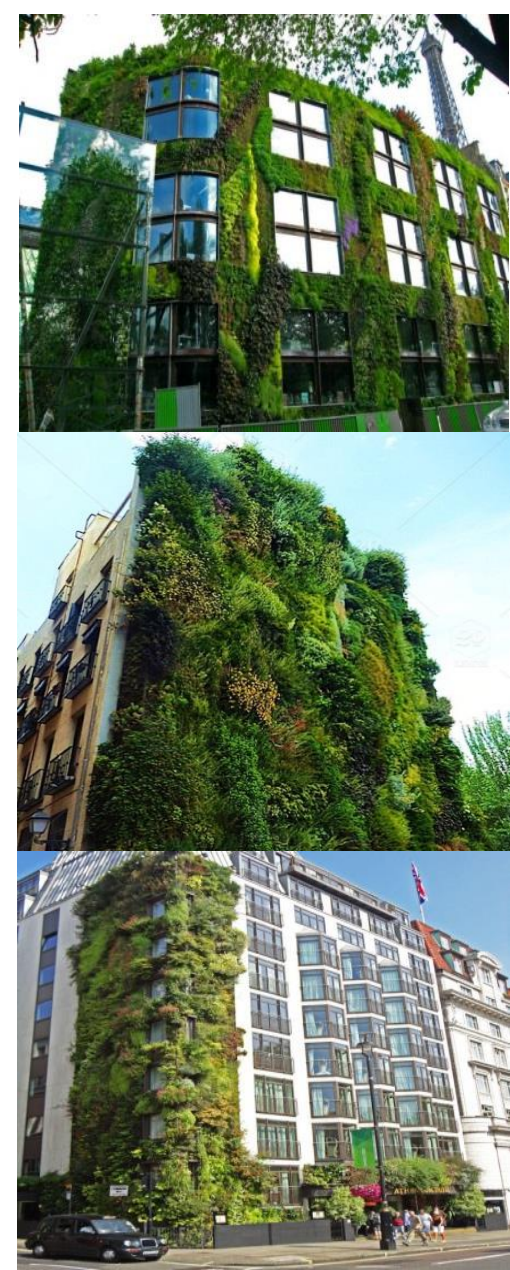

Sekil 3. Sıralı olarak Quai Branly Müzesi-Paris, Madrid'den dikey bahçe örneği [19]. Athenaeum Hotel-Londra, [7]. 


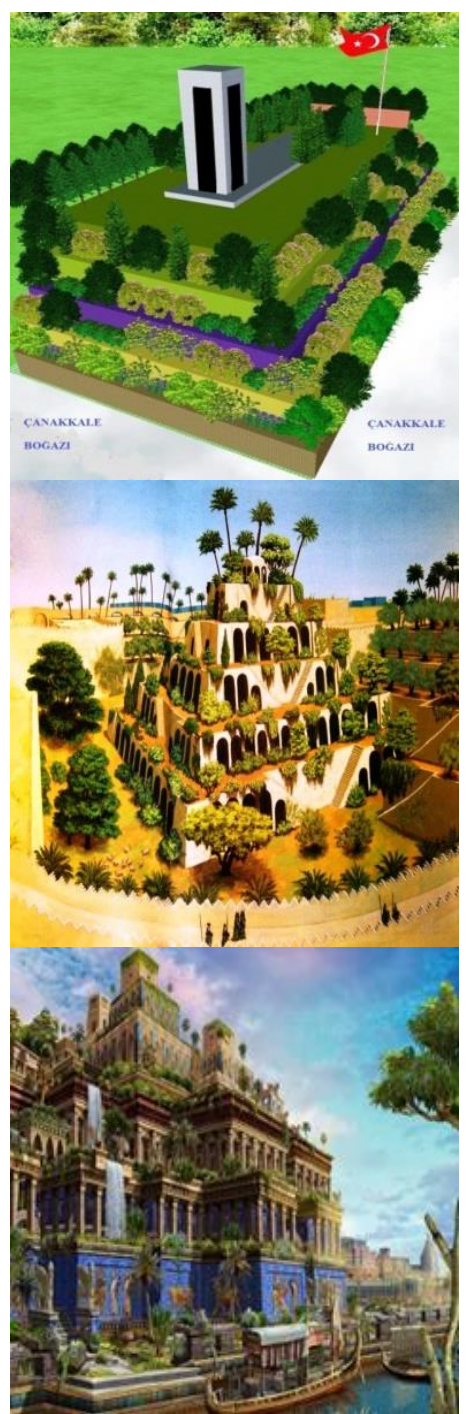

Şekil 4. Sıralı olarak Çanakkale Şehitler Abidesi teras bahçe sistemi, Mezopotamya'da bulunan Babil'in Asma Bahçeleri [19].

Çalışmanın yürütüldüğü Çanakkale Şehitler Abidesi mevcut şev alanının yetersiz bitki popülasyonu, yüksek eğim ve 50 metrelik rakımdan kaynaklı toprak kayması ya da erozyon riskine karşı istinat duvarları tasarısı ile yatay ve dikey bitkilendirmelerin yanı sıra alana kazandırılan estetik ve rekreasyonel kullanımlar sayesinde alanın daha optimal/rasyonel kullanımına olanak sağlanabilecektir.

Çanakkale Şehitler Abidesi şev alanın hesaplanmasında aşağıda yer alan formül kullanılmıştır (1). Alan şev yapısalının rakımı 50 m; yatay mesafesi ise yaklaşık $80 \mathrm{~m}$ bulunmuştur (Google Earth 2019) Şev alanının eğimi yaklaşık \% 62,5 hesaplanmıștır. [14], (Şekil 5).

$$
\begin{gathered}
\text { Eğim }=\frac{\text { Yükselti Farkı (h) }}{\text { Yatay Uzunluk (L) }} \times 100 \\
\text { Eğim }=\frac{50 \mathrm{~m}}{80 \mathrm{~m}} \times 100=\% 62.5
\end{gathered}
$$

Şev alanındaki \% 62,5 eğimin mevcut doğal bitki örtüsü dağılımı ile birlikte heyelan riskini arttırdığını söyleyebiliriz (Şekil 5).

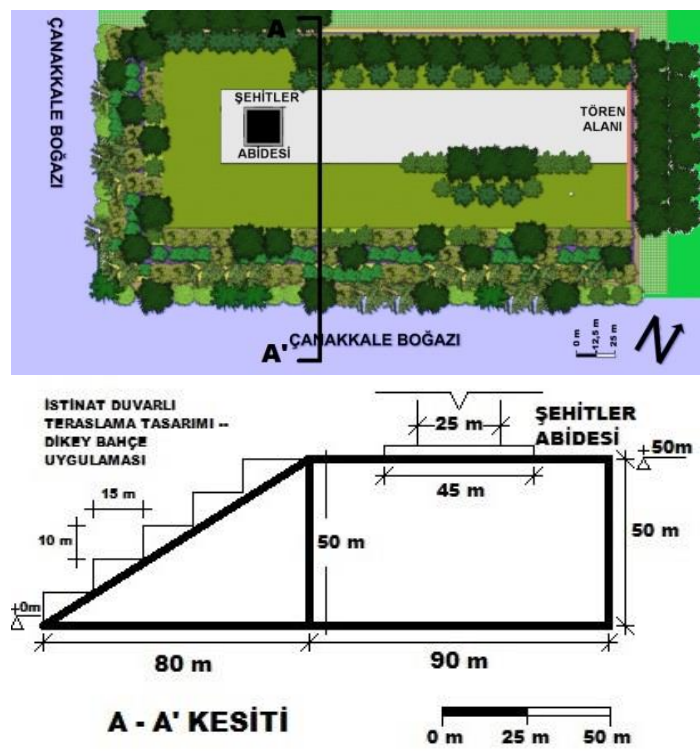

Şekil 5. Çalıșma alanı (Şehitler Abidesi) perspektif üst görünüşü ve A-A' kesit görünümü

Çanakkale Şehitler Abidesi şev alanında mevcut doğal bitki türleri ağırlıklı olarak maki bitki topluluğundan oluşmaktadır. Atriplex halimus (Tuz çalısı), Medicago arborea (Yonca çalısı), Vibirnum tinus (Kartopu), Hedera spp. (Kaya sarmaşığı), Oenothera lindheimeri (Gavura çiçeği), Carex spp. (Çalı görünümlü sazlıklar), Arbutus andrachne (Sandal ağacı), Calluna vulgaris (Süpürge çalısı), Erica arborea (Ağaç fundası), Erica manipuliflora (Funda), Rhododendron ponticum (Orman gülü), Vaccinium arctostaphylos (Çoban üzümü), Vaccinium corymbosum (Yaban mersini), Vaccinium myrtillus (Adi yaban mersini), Olea oleaster (Yabani zeytin,Delice), Quercus coccifera (Kermes meşesi), Juniperus oxycedrus (Kadran ardıcı), Fragaria vesca (Dağ çileği), Ceratonia sliqua (Keçi boynuzu), Cistus spp. (Laden), Rubus caesius (Böğürtlen), Laurus nobilis (Akdeniz defnesi), Pistacia lentiscus (Sakız ağacı), Eleagnus angustifolia (Kuş iğdesi), Salix babylonica (Söğüt), Ulmus carpinifolia (Dağ karaağacı), Populus alba (Akkavak) alanda tespit edilen bitki türleridir.

Doğal afetler grubunda yer alan toprak kayması (heyelan), şev stabilizasyonunun bozulmasıdır [20]. Yer çekimi devinimi ile ortaya çlkan bu durum insan faktörü veya doğal faktörlerin ya da her ikisinin birlikte tetiklemesi ile ortaya çıkmaktadır. Devinimin hızını ve derecesini belirleyen bazı dış faktörler mevcuttur. Eğim fazlalığı, yıllık yağıŞ yoğunluğu, bitki örtüsü zayıflığı, deprem bölgesinde yer alması heyelan oluşumunu ve etki derecesini etkileyen önemli etkenler arasındadır. Toprak yapısı ve eğim ise bunların arasında en önemlilerindendir [21]. Toprak yapısında bağlayıcı toprak sınıfının bulunmaması veya düșük oranda bulunması; başka bir deyişle kil ağırlıklı toprak yapısı toprağın 
kaymasında/yer değiştirmesinde hızlandırıcı bir faktördür. Eğimin fazla olması, yer çekimini artırmakta buna bağlı olarak toprak kayması da artmaktadır. Eğimin etkisiyle toprağın yer değiștirmesi, "toprak kayması"; toprağın katman/tabaka olarak yer değiştirmesi "heyelan" olarak tanımlanmaktadır [20]. Bu vakalar yeryüzünün değişmesinde önemli etkenlerdir. Topoğrafya ile heyelanlar arasında sıkı bir ilișki vardır. Öyle ki eğimin olmadığı yerde toprak kaymasından söz edilemez [20]. Sözü edilen çevresel faktörler, hem bölgenin topoğrafik, jeolojik, klimatik ve bitki örtüsü özelliklerine hem de 'Șehitler Abidesi" şevine etki yapmaktadır. Şev alanının heyelean riskini azaltmak, stabilizasyonunu güçlendirmek için sağlam kaideler üzerinde bitkilendirme yapılması düşünülmüştür. Bu işlem için Şehitler Abidesi ile şev yapısalının kesit görünümünden hareketle (Şekil 5) 80*50 metre dik kenarlara sahip bir dik üçgen üzerinde yaklaşı 10 metre yükseklik ve 15 metre eninde yatay zemine sahip 5 basamaklı teraslama yapılarak (Şekil 5); dikey ve yatay boyutlarda bitkilendirme alanları oluşturulması düşünülmüştür (Şekil 6-8).

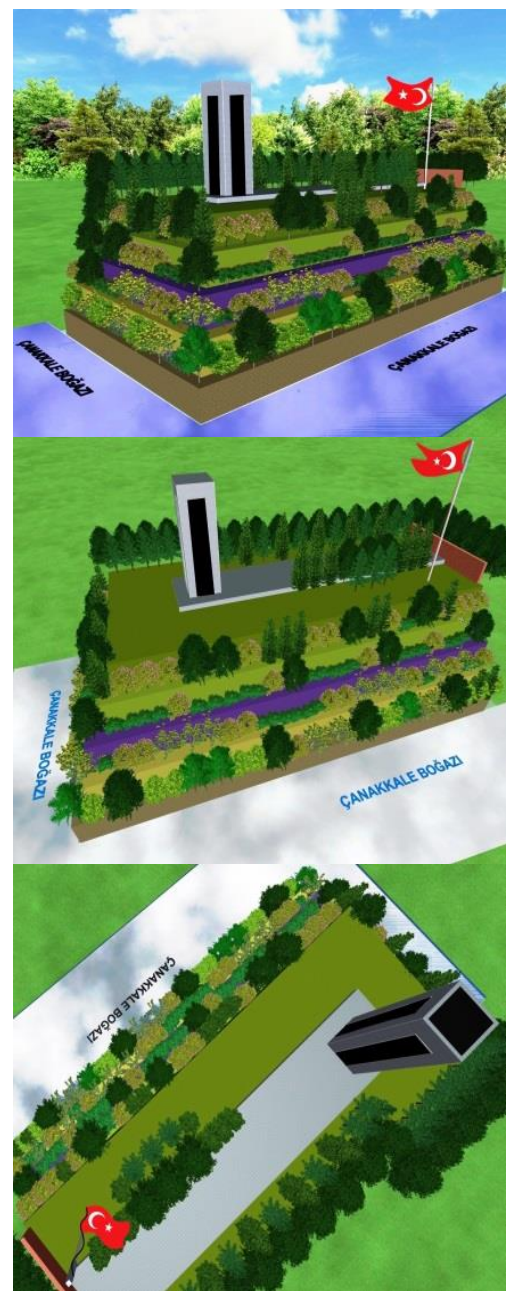

Şekil 6. Şehitler Abidesi şev alanı bitkisel tasarım örneğinden farklı açılardan perspektif görünümler

İstinat duvarlarının dikey cephelerinde bitkilendirmesinde ön görülen bitki türleri: Hedera helix (Duvar sarmaşı̆̆ı), Parthenocissus ouinquefolia (Amerikan sarmaşı̆̆ı), Parthenocissus tricuspidata (Amerikan saarmaşığı) gibi tırmanıcı türler, Hydrangea petiolaris (Ortanca), Euonymus fortunei (Taflan) türleridir. Sarılıcı türler; çelik tel, ahşap kafes gibi özel yapılarda yer almak üzere, Passiflora caerulea (Çarkıfelek), Lathyrus odoratus (Nazende çiçeği), Polygonum cuspidatum (Japon madımağı), Lonicera periclymenum (Hanımeli), Clematis vitalba (Akasma), Humulus lupulus (Şerbetçiotu), Jasminum officinale (Yasemin), Vitis spp. (Asma üzüm)türlerin kullanılması düşünülmektedir. Ayrıca geven, kazayağı, sedum, telgraf çiçeği, yayvan ardıç gibi özellikle sukulent/kurakçıl çok yıllık bitki türlerinin bu alanda kullanılması uygun görülmektedir.Bu bitkilerin dışında Wisteria sinensis (Mor salkım), Campsis radicans (Acem borusu), Bougainvillea glabra (Gelin duvağı) gibi süs bitkilerinin de kullanılması planlanmıştır (Şekil 6-8). Tasarımda kullanılması düşünülen bitkilerde bitkinin yaşı cinsi, gelișme gücü ve yönü, taç formu, boyu, yaprak döken ya da her dem yeşil olmaları, çevre şartlarına uyumlu olmaları, olumsuz çevre şartlarına dayanıklılık ve suya karşı toleransı yüksek olması gibi bitki özellikleri bitki seçiminde dikkat edilmesi gereken unsurlardır. [19]. Ayrıca, dikey cephelerde yer yer tarihi alanının anlam ve önemine vurgu yapan kabartma resimlere (röliyef) yer verilmesi de planlanmaktadır (Şekil 6-8).

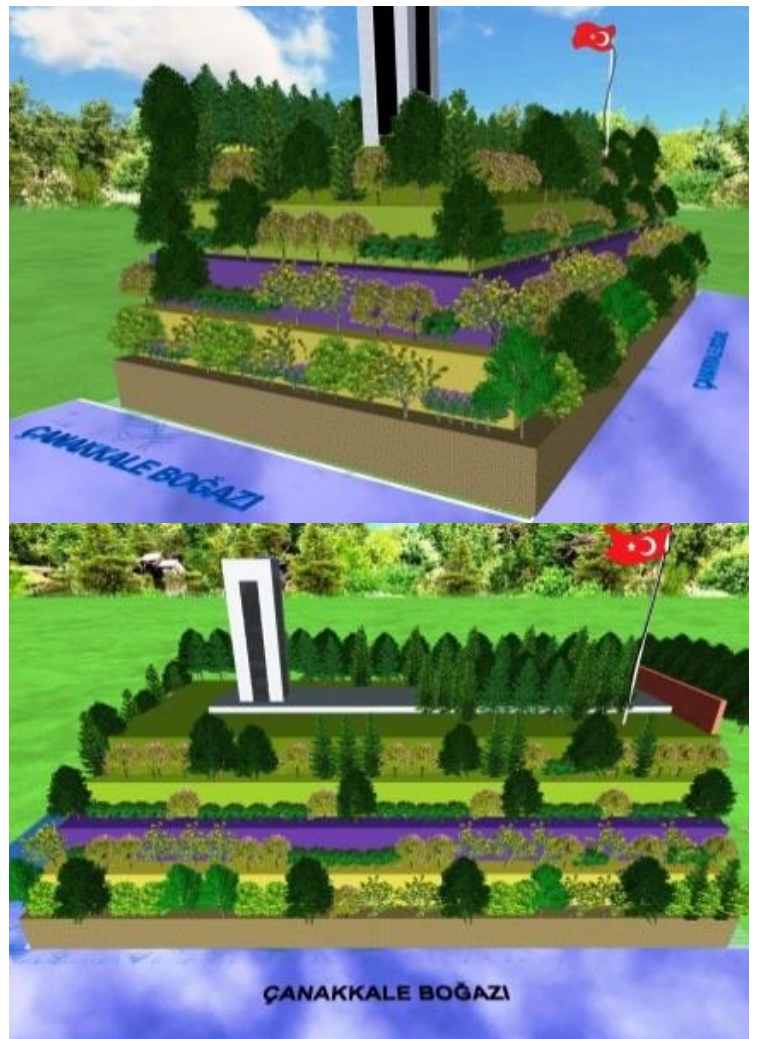

Şekil 7. Şehitler Abidesi șev alanı bitkisel tasarım örneğinin farklı açllardan perspektif görünümleri.

Teraslama sonucu oluşturulan dikey bahçe uygulamasında basamak zeminin bitkilendirmesinde bölge, iklim ve tasarım amacına uygun ağaç ve çalı 
grubu bitkiler düşünülmüştür. Bu bitkiler; Cupressus sempervirens var. pyramidalis/horizontalis (Servi), Pinus pinea (Fıstık çamı); Pinus sylvestris (Sarı çam), Acacia dealbata (Akasya), Cedrus libani (Toros sediri), Quercus coccifera (Kermes meșesi), Abies bornmülleriana (Uludağ göknarı), Abies clicica (Toros göknarı), Populus alba (Ak kavak), Lagerstroemia indica (Oya ağacı) Arbutus andrachne (Sandal ağacı), Taxus baccata (Porsuk ağacı), Ginkgo bloba (Mabet ağacı), Fraxinus excelsoir (Adi dişbudak), Laurus nobilis (Defne). Prunus laurocerasus (Bodur karayemiş), Buxus sempervirens (Bodur şimşir), Acacia dealbata (Mimoza ağaci), Cupressus macrocarpa (Limoni servi), Cupressocyparis leylandii (Leylandi ağacı), Photinia fraseri (Alev ağacı), Ligustrum japonicum (Kurt bağrı), Cotoneaster horizontalis (Dağ muşmulası), Juniperus horizantalis (Yayılıcı ardıç) türlerinden oluşmaktadır (Şekil 6-8).

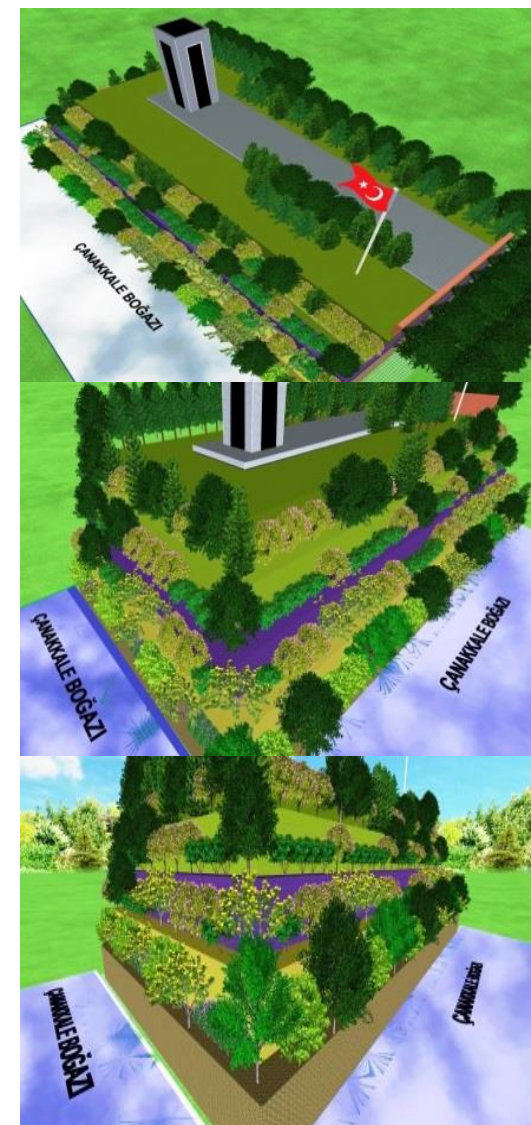

Şekil 8. Şehitler Abidesi şev alanı bitkisel tasarım örneğinin farklı açllardan perspektif görünümleri.

\section{Tartışma ve Sonuç}

$\mathrm{Bu}$ çalıșmayla Çanakkale Șehitler Abidesi șev stabilizasyonu sağlamak için bitkilendirme ve istinat duvarı bileşenleri ile tasarım önerisi geliştirilmiş ve bu öneriler literatür karşılaștırmaları yapılarak alanın daha verimli kullanımı için geliştirilmiştir. Şehitler Abidesi şevinde teraslama ile oluşturulan dikey bahçe tasarımının alanda öne çıkan rüzgar, toz, güneş gibi faktörlerinin giderilmesinde veya azaltılmasında pozitif etkisi ön görülmektedir. Çerçi [10] mimari yapılarda yeşil duvarlar ve çatılar tasarlamanın binaların yalıtımı üzerine olumlu katkılar yaptığını, ayrıca kentsel ısı adacıklarının serinlemesinde önemli bir paya sahip olduğunu ifade etmiştir. $\mathrm{Bu}$ çalışmada da kentsel peyzaja katkı verilmişve yapılan tasarım önerisiyle alandaki bitki ve hayvan varlığına da yaşam alanı oluşturulması öngörülmüştür. Yalçınalp vd. [13] kentsel alan içindeki dikey bahçe tasarımında yenilebilir tarımsal bitkilerin kullanılabileceğini vurgulamışlardır. Bu çalışmada benzer bitkilerin kullanılma olasılığı bulunurken çalıșmanın yapıldığı alanın kensel alan dışında bulunduğu göz ardı edilmemelidir. Kırıt ve Sağlık [4] dikey bahçe; tarihsel sürecini, dünya ve Türkiye'den örneklerle, estetik ve işlevsel yönünü belirtmişlerdir. Tasarım önerisinin geliştirilmesinde faydanılan estetik ve işlevsel öneriler bu çalışmayla örtüşmektedir. Ekren [3] dikey bahçelerin işlevsel ve estetik yönden olumlu ve olumsuz taraflarından bahşetmiş, olumsuz taraflarının nedenleri ve bunun sonucu olarak uygulama oranındaki düşüşe dikkat çekmiştir. Bu çalışmada da olduğu gibi uygulamanın iklimsel faydaları ve sürdürülebilirliğine işaret etmiştir. Gürel ve Kalyoncuoğlu Gürel [11] bu çalışma ile örtüşecek tarzda açık ve yeşil alanlar aleyhine yapısal unsurların ağırlık kazanmasıyla sağlıksız gelişen kentlerde, alternatif peyzaj tasarımlarından dikey bahçelerin kent dokusunda estetik olarak kent kimliği; işlevsel olarak, kent iklimi, doğal yaşam, gürültü ve görüntü kirliliği, birey psikolojisi gibi hususlarda etkin rol üstlendiği vurgulamaktadırlar.

Başdoğan ve Çı̆̆ [1] sürdürülebilir kent modellerinin oluşturulmasında yapı cephelerinde bitkilendirme uygulamalarına değinmişlerdir. Yaşayan duvarlar olarak yeşil cepheler/dikey bahçeler kent ekolojisinde ve kentsel refahın artmasında etkili unsurlar olduğundan bahsetmektelerdir. Bu çalışmayla paralel olarak dikey bahçelerin estetik ve işlevselliklerinin yanı sıra ekonomik, ekolojik ve sosyal açıdan sürdürülebilir kent modeline katkılarına değinmişlerdir. $\mathrm{Bu}$ çalışmada istinat duvarı ile birliktelik teşkil eden bitki türlerinin şekil, boy, hacim gibi fiziksel özellikleri ile ekolojik, jeolojik, iklimsel etkilerine vurgu yapılmıştır. Benzer şekilde Carpenter [12]'ın yaptığı çalıșmada da dikey bahçede kullanım potansiyeline sahip bitkilerin fiziksel özelliklerinden bahsedilmiştir. Ayrıca uygulamada yer alan bitki türleri aracılığıyla ekoloji üzerine olumlu etkileri de vurgulanmıştır. Yine bu çalışmada yapılaşmalardaki yoğunluğa bağlı olarak kent tekstüründeki açık ve yeşil alanların azlığına işaret edildiği gibi Rafiee vd. [2]'nin yaptıkları çalışmada da artan nüfus ve yapılaşmalara paralel olarak azalan yeşil alanlardan bahsedilmektedir. Çakır vd. [8]'nin yaptıkları çalışmada; Amerikan asma bitkisi ile yapılan dikey bahçe uygulamasının, insan psikolojisindeki etkilerini estetik kriterleri, ayrıca bitkinin fizyolojik gelişimlerini değerlendirmişlerdir. Timur vd. [9] çalıșmalarında, gelecekteki kent nüfus potansiyellerinin artışına paralel olarak doğadan uzaklaşan insanların yaşam standartlarını artırmak, 
kente estetik ve işlevsel kullanımların yanı sıra birey psikolojisi üzerine etkilerine değinmişlerdir. Çalışmalarında özellikle karasal bölgeler için örnek teşkil edebilecek Ankara Sıhhiye Köprüsü'nün yeşillendirme çalışması dikey yönde olan boyutuyla bu çalışmayla örtüşmektedir. Yıldız [6] yaptığı çalışmada, dikey bahçelerin doğal yaşamın belirleyicisi olarak, estetik, işlevsel, hobi, kuş ve böcekler için yaşam alanı olması ile gürültü ve görüntü kirliliğini önlemek amaçlı, kent insanı için vazgeçilmez peyzaj donatıları olduğundan bahsetmektedir. Söz konusu ekstrem peyzaj donatılarının Şehitler Abidesi'nin her yıl özellikle yaz aylarında gerek yerli gerekse yabancı turizm yoğunluğu nedeniyle doğal, estetik ve fonksiyonel anlamda alana kazandırılması turist yoğunluğundaki artışı ile turistler üzerinde bıraktığı olumlu etkileri de beraberinde getirmesi planlanmaktadır [17]. Çalışmadan elde edilen sonuçlar ve bu doğrultuda geliştirilen önerilere aşağıda yer verilmiştir.

* Çalışmayla alana kazandırılacak istinat duvarlarıyla alanın șev yapısında jeolojik ve ekolojik faktörlere bağlı olarak oluşabilecek toprak taşınmasının/kaymasının gerçekleşme olasilıklarının en aza indirgemesinin de sağlanması ön görülmektedir.

* Teraslama ile oluşturulan sistemde yatayda ağaç, ağaççık ve çalı formlu bitkiler ile çim alan tesisi; dikeyde ise, sarılıcı, sarkıcı, sürünücü ve yayllıcı gelişme gösteren bitkilerin kullanılması düşünülmektedir. Böylelikle alanda ekolojik, estetik ve fonksiyonel alan kullanımları ortaya konabilecektir.

* Tasarım kazanımı olarak turistlerin gezi-gözlem ve regreasyonel amaçlı terasları kullanabilme şansları ortaya çıkmıştır. Abide alanı dikey bahçe uygulaması kapsamında, alanın jeolojik açıdan tarıma elverişli toprak yapısına ve ekolojik faktörlerine bağlı olarak bakım ve onarımı uygun yapısal unsurların ve bitkisel materyallerin kullanımı ile alan için yeterli estetik, fonksiyonel ve sürdürülebilir optimal alan kullanımı sağlanmalıdır.

* Alandaki toz, rüzgar ve güneşin olumsuz etkilerine karşı planlamanın işlevselliği öne çıkmaktadır.

* Alana özgü şev planlaması ile toprak kaymasının uzun vadede önüne geçilmesi planlanmalıdır.

* Dikey bahçe uygulamasının, alan için hem fiziksel hem de fonksiyonel açıdan katkı sağlama potansiyeli göz ardı edilmemelidir.

- Dikey bahçe olarak tasarlanması planlanan alanda aynı zamanda rekreasyonel aktivitelerin de yapılabilir olduğu önemsenmelidir.
* Alanda teraslama yöntemi ile dikey bahçe tasarımının sergilenmesi; Abide alanının artan bir ziyaret alanı sunumunu da beraberinde getirecektir. Öyle ki; bu durum ziyaret alanının yaklaşık iki katına çıkması anlamına gelmektedir.

* Çalışma kapsamında sulama, drenaj ve gübreleme entegrasyonun sağlanması gerekliliği önemsenmelidir.

$\mathrm{Bu}$ çalışmada ortaya konan bu tasarımla sulama, toprak yapısı, gübreleme, drenaj boyutlarına değinilmemiştir. Alanın özgün eğimli yapısı ve bitkilendirme potansiyelindeki zayıflıktan yola çıkılarak, alan kaidesinin güçlendirilmesi ve alanda dikey bahçe uygulamasına yönelik tasarım çalışması ile sınırlı tutulmuştur. Alanın doğal ve kültürel dış etkenlere karşı mukavemetini (rijit özelliğini) artırarak, uzun süreler mevcut durumunun korunması, kullanılması ve sürdürülebilir kılınması amaçlanmıştır. Çalışma sonuçları itibarıyla ileri boyutta planlanan çalışmalara zemin hazırlaması bakımından özgün bir çalışmadır. Öyle ki, alanın drenaj, sulama, toprak yapısı, gübreleme tekniklerini kapsayan kapsamlı ve birbirini bütünleyen farklı çalışmalarla desteklenmesinin önü açılmış olabilecektir.

NOT: Bu makale, Kasım 11-13, 2019'da KonyaEreğli'de gerçekleștirilmiş olan IV. İNSAC Mimarlık, Tasarım ve Güzel Sanatlar Kongre'sinde Bildiri olarak sunulmuştur.

\section{Kaynakça}

[1] Başdoğan, G. ve Çiğ, A. 2016. Ecological-SocialEconomical Impacts of Vertical Gardens in the Sustainable City Model. Yüzüncü Yıl Üniversitesi Tarım Bilimleri Dergisi, 26(3), 430-438.

[2] Rafiee, R., Mahiny, A.S., Khorasani, N. 2009. Assessment of Changes in Urban Green Spaces of Mashad City Using Satellite Data. International Journal of Applied Earth Observation and Geoinformation, 11(6), 431-438.

[3] Ekren, E. 2017. Dikey Bahçelerin Avantajları ve Riskleri. Bartın Orman Fakültesi Dergisi, 19(1), 51-57.

[4] Kırıt, N., Sağlık, A. 2018. Kentsel Peyzaj Tasarımında Dikey Bahçe Uygulamaları. Uluslararası Hakemli Tasarım ve Mimarlık Dergisi, 13, 161-179.

[5] Olgun, R., Yllmaz, T. 2019. İmar Planlarının Peyzaj Ekolojisi Yaklaşımı ile Değerlendirilmesi: Niğde Kenti Örneği. Süleyman Demirel Üniversitesi Fen Bilimleri Enstitüsü Dergisi, 23 (3), 770-779.

[6] Yıldız, M. 2014. Dikey Bahçe; Beton Yapıların Yeni Yeşil Yüzü. Ekoyapı Dergisi, https://www.ekoyapidergisi.org/815-dikey- 
bahce-beton-yapilarin-yeni-yesil-yuzu.html (Erişim Tarihi: 29.12.2019).

[7] Anonim, 2019a. Yaşayan Duvarlar. https://listelist.com/dikey-bahce/ (Erişim Tarihi: 29.12.2019).

[8] Çakır, A., Yalcınalp, E., Doğan, E., Meral, A. 2017. Determination of the Suitability of Some American Grapevine Rootstocks as a New Edible Landscape Component of Vertical Gardens. Journal sustainability, 9, 1275.

[9] Timur, Ö., B., Aytaş, İ., Özden, F., Akyol, E., Yazıcı, B., Ataoğlu, F. D. 2018. Vertical Garden Design in Case of Ankara Sihhiye Bridge and Closed Area. Journal of Bartin Faculty of Forestry, 20(1), 5362.

[10] Çerçi, S. 2018. Bitkilendirilmiş Cephelerin Cevresel ve Ekolojik Etkileri., 9. Ulusal Catı \& Cephe Sempozyumu, Nisan, İstanbul, 12-13.

[11] Gürel, J., Kalyoncuoğlu, B.B. 2017. Dikey Bahçelerin Kentli Algısı ve Kentsel Psikoloji Açısından Değerlendirilmesi. Ekoyapı Dergisi. https://www.ekoyapidergisi.org/3904-dikeybahcelerin-kentli-algisi-ve-kentsel-psikolojiacisindan-degerlendirilmesi.html (Erişim Tarihi: 29.12.2019).

[12] Carpenter, S. 2014. A Guide to Green Roofs, Walls and Facades in Melbourne and Victoria, Australia. State of Victoria Through the Department of Environment and Primary Industries, Australia, 131p.

[13] Yalçınalp, E., Meral, A., Doğan, E. 2017. Duvar Yüzeylerindeki Tarımsal Kaçakların Belirlenmesi ve Duvarlarda Yenilebilir Peyzaj Potansiyelinin Geliștirilmesi. Türk Tarım ve
Doğa Bilimleri Dergisi 4(2): 169-178.

[14] Atabay, M. 2016. Şehitlikleri İmar Cemiyeti Arșiv Belgelerine Göre Çanakkale Şehitler Abidesi İnşaatının Tamamlanması ve Açılış Töreni Çanakkale Araştırmaları Türk Yıllığı, 14(21), 213-232.

[15] Erginbaş, D. 1958. İsmail Utkular, "Çanakkale Abidesi," Arkitekt, c. 4 (293) 148-150.

[16] Cihangir, Y. 1979. Çanakkale Meçhul Asker Anıtı, İstanbul Üniversitesi Edebiyat Fakültesi Sanat Tarihi Bölümü, Yayınlanmamış Mezuniyet Tezi, 32-33, İstanbul.

[17] Alkan, Y. 2019. Çanakkale Şehitler Abidesi Peyzaj Planlama ve Tasarımında Yeni Bir Yaklaşım. Turkish Journal of Forest Science, 3(2), 142-148.

[18] Anonim, 2019b. Dikey Bahçe Örnekleri. https://www.yesilist.com/dunyanin-en-buyukdikey-bahcesi-85-bin-bitki-ile-kolombiyadayukseliyor/ (Erişim Tarihi: 29.12.2019).

[19] Anonim, 2019c. Milli Eğitim Bakanlı̆̆ı, MEGEP (Mesleki Eğitim ve Öğretim Sisteminin Geliştirilmesi Projesi), Tarım, Dikey Bahçeler. http://megep.meb.gov.tr/mte_program_modul/ moduller/Dikey\%20Bah\%C3\%A7eler.pdf (Erişim Tarihi: 29.12.2019).

[20] Öztürk, G. 2002. Heyelanlar ve Türkiye'ye Etkileri. G.Ü. Gazi Eğitim Fakültesi Dergisi, 22 (2), 35-50.

[21] Kahraman, Ö., Aktaş, M., Yurtsever, N. (2018). Çatı ve Dikey Bahçeler Bakımından Çanakkale Kent Merkezinin Değerlendirmesi. ÇOMÜ Ziraat Fakültesi Dergisi, 6, 153-159. 